\title{
Fresh-market Carrot Yield and Quality Did Not Respond to Potassium Fertilization on a Sandy Soil Validated by Mehlich-1 Soil Test
}

\author{
George J. Hochmuth ${ }^{1}$, Jeffrey K. Brecht ${ }^{2}$, and Mark J. Bassett ${ }^{2}$
}

AdDITIONAl INDEX WORDs. carotene, Daucus carota, nutrient uptake, plant nutrition, plant tissue analyses, soil testing, sugars

\begin{abstract}
Summary. Potassium (K) is required for successful carrot (Daucus carota) production on sandy soils of the southeastern United States, yet there is little published research documenting most current university Cooperative Extension Service recommendations. Soil test methods for $\mathrm{K}$ in carrot production have not been rigorously validated. Excessive fertilization sometimes is practiced by carrot growers to compensate for potential losses of $\mathrm{K}$ from leaching and because some growers believe that high rates of fertilization may improve vegetable quality. Carrots were grown in three plantings during the winter of 1994-95 in Gainesville, Fla., to test the effects of $\mathrm{K}$ fertilization on carrot yield and quality on a sandy soil testing medium (38 ppm) in Mehlich-1 soil-test K. Large-size carrot yield was increased linearly with $\mathrm{K}$ fertilization. Yields of U.S. No. 1 grade carrots and total marketable carrots were not affected by $\mathrm{K}$ fertilization. $\mathrm{K}$ fertilizer was not required on this soil even though the University of Florida Cooperative Extension Service recommendation was for $84 \mathrm{lb} /$ acre K. Neither soluble sugar nor carotenoid concentrations in carrot roots were affected by $\mathrm{K}$ fertilization. The current $\mathrm{K}$ recommendation for carrots grown on sandy soils testing $38 \mathrm{ppm}$ Mehlich-1 K could be reduced and still maintain maximum carrot yield and root quality.
\end{abstract}

$\mathrm{C}$ arrot is an important vegetable crop in the southeastern U.S. There were 7000 acres planted in Florida during the 1995-96 season, the latest season for which statistics were reported (Florida Agricultural Statistics Service, 1997). A similar amount of carrots is grown in the region today, but the production area has shifted. Most of the carrots in the mid 1990s were grown on organic soils in central and southern Florida. These Histosol-based production areas have come under scrutiny as potential sources of nutrients contributing to the eutrophication of lakes, for example, Lake Apopka in central Florida (Conrow, 1989; Crnko et al., 1993). Recently the Histosol farming area, Zellwood, Fla., near Lake Apopka, was flooded and farming ceased, displacing a large portion of Florida's carrot production. Carrot growers are searching for alternative production areas as the Histosols are increasingly regulated

Florida Agricultural Experiment Station Journal Series R-11042.

${ }^{1}$ Horticultural Sciences Department and Center Director, North Florida Research and Education Center, University of Florida, Quincy, FL 32351.

${ }^{2}$ Horticultural Sciences Department, University of Florida, Gainesville, FL 32611. or as crop production on these soils is prohibited.

Sandy soils are well-suited for carrot production (Boswell, 1963) and are used for this purpose in many states. Research on carrot production on sandy soils was conducted in the early 1960s in Florida (Forbes and Scudder, 1963). However, commercial growers came to prefer organic soils over mineral soils because of the ease of tillage of these soils and the potential for fallow flooding to reduce pest problems (Moore, 1949; Strandberg, 1984). The cessation, in the 1990s, of crop production on the Histosols in central Florida forced growers to return to carrot production on mineral soils.
One of the challenges of early carrot production on sandy soils in Florida was crop fertilization, particularly the mobile nutrients nitrogen $(\mathrm{N})$ and $\mathrm{K}$ (Forbes and Westgate, 1963). There have been numerous studies on $\mathrm{N}$ fertilization of carrot growing on sandy soils in Florida (Forbes and Westgate, 1963; Hochmuth et al., 1999) and elsewhere in the world (Evers, 1989a, 1989b; Hartz et al., 2005; Hemphill and Jackson, 1982; Hipp, 1978; Sanderson and Ivany, 1997). In recent studies, carrot yield in Florida was shown to increase with $\mathrm{N}$ fertilization, maximizing with 125 $\mathrm{lb} /$ acre $\mathrm{N}$ for fall plantings and with $160 \mathrm{lb} /$ acre $\mathrm{N}$ with winter plantings (Hochmuth et al., 1999).

There are few reports on $\mathrm{K}$ fertilization of carrot. Yields of 'Chantenay' and 'Imperator' carrots did not respond to K fertilization from 0 to $240 \mathrm{lb} /$ acre Kon sandy soils in central Florida that tested high in ammonium acetate extractable soil-K (Forbes and Westgate, 1963). In a study in Bangladesh on a sandy loam soil (no soil-test results provided), carrot yield responded to $\mathrm{K}$ fertilization, maximizing with $220 \mathrm{lb} /$ acre K (Ali et al., 2003). Carrot yield in Finland increased with band placement of phosphorus (P) and K compared to broadcasting (Evers, 1988, 1989b). There have been no recent reports in the literature of studies of $\mathrm{K}$ fertilization of carrots grown on sandy soils in Florida or the southeastern U.S.

Researchers typically have focused on vegetable yield responses to fertilization, seldom evaluating product quality characteristics, such as sugar or carotenoid concentrations. There have been reports on the influence of fertilization on compositional quality of vegetables (Follett, 1991; Locascio et al., 1984; Mengel, 1979; Mozafar, 1993; Ventner, 1979; Wong et al., 1995 ). In carrot, carotenoid content is

\begin{tabular}{lllc}
\hline $\begin{array}{l}\text { Units } \\
\begin{array}{l}\text { To convert U.S. to SI, } \\
\text { multiply by }\end{array}\end{array}$ & U.S. unit & SI unit & $\begin{array}{l}\text { To convert SI to U.S., } \\
\text { multiply by }\end{array}$ \\
\hline 0.4047 & acre(s) & $\mathrm{ha}$ & 2.4711 \\
1 & $\mathrm{cbar}$ & $\mathrm{kPa}$ & 1 \\
0.3048 & $\mathrm{ft}$ & $\mathrm{m}$ & 3.2808 \\
2.54 & inch(es $)$ & $\mathrm{cm}$ & 0.3937 \\
25.4 & inch(es & $\mathrm{mm}$ & 0.0394 \\
1.1209 & lb/acre & $\mathrm{kg} \cdot \mathrm{ha}^{-1}$ & 0.8922 \\
0.001 & $\mathrm{ppm}$ & $\mathrm{mg} \cdot \mathrm{g}^{-1}$ & 1000 \\
1 & $\mathrm{ppm}$ & $\mathrm{mg} \cdot \mathrm{kg}^{-1}$ & 1 \\
1 & $\mathrm{ppm}$ & $\mu \mathrm{\mu g} \cdot \mathrm{g}^{-1}$ & 1 \\
2.2417 & ton $/ \mathrm{acre}$ & $\mathrm{Mg} \cdot \mathrm{ha}^{-1}$ & 0.4461 \\
$\left({ }^{\circ} \mathrm{F}-32\right) \div 1.8$ & ${ }^{\circ} \mathrm{F}$ & ${ }^{\circ} \mathrm{C}$ & $\left(1.8 \times{ }^{\circ} \mathrm{C}\right)+32$ \\
& & &
\end{tabular}


related to vitamin A content, and sugars are associated with sweet flavor. Flavor components of carrot are influenced by genetic and environmental factors (Rosenfeld et al., 1998; Simon and Peterson, 1979; Simon et al., 1980, 1982).

Nitrogen fertilization has received most of the attention of researchers studying the effects of fertilization on carrot root quality. Few researchers have measured root quality responses to Kfertilization. For example, greater rates of $\mathrm{N}, \mathrm{P}$, and $\mathrm{K}$ fertilization led to reduced sugar concentration of carrots in Finland (Evers, 1989b). Carotene concentration of carrots was increased by band placement of $\mathrm{P}$ and $\mathrm{K}$ fertilizers, but was not improved by increasing $\mathrm{N}$ from 70 to $130 \mathrm{lb} /$ acre (Evers, 1989a). Increasing $\mathrm{N}$ rates were associated with increasing carotene concentrations in one study (Freeman and Harris, 1951), but in another study, the reverse relationship was observed (Southards and Miller, 1962). Those $\mathrm{N}$ fertilization rates that maximized carrot root yield also maximized carrot quality as defined by sugar and carotenoid concentrations (Hochmuth et al., 1999). Potassium fertilization was associated with increases in carotene concentration in the carrot root but with decreases in reducing sugar concentration (Ali et al., 2003).

Much of the carrot production in Florida has been moved to the sandy soils for which little is known about carrot $\mathrm{K}$ fertilization requirements. Carrots are an important crop and fertilization can have a large impact on carrot yield and quality. It is important to evaluate carrot responses to $\mathrm{K}$ on sandy soils and to build a database of crop response for soil test-based fertilization recommendations. This study was conducted to evaluate carrot yield and root quality (as determined by alcohol-soluble sugar and total carotenoid concentrations) responses to $\mathrm{K}$ fertilization on a sandy soil in three plantings made in the winter growing season of 1994-95 in north-central Florida.

\section{Materials and methods}

Research was carried out at the Horticultural Research Unit of the University of Florida in Gainesville during the winter of 1994-95 in a field that had been fallow (no cover crop) for the previous 6 months. The soil, an Arredondo fine sand (loamy, siliceous, Hyperthermic Grossarenic Paleudults), was moldboard-plowed to a depth of 8 inches and disked in early Nov. 1994. Prefertilization soil samples were taken with a soil probe from the top 6 inches of soil, the recommended depth for soil nutrient testing. Soil was dried, sieved, and analyzed (test result in parentheses) for $\mathrm{P}$ (medium), calcium (medium), magnesium $[\mathrm{Mg}$ (medium)], copper (high), manganese $[\mathrm{Mn}(\mathrm{low})]$, and zinc $[\mathrm{Zn}(\mathrm{low})]$ with Mehlich-1 procedures (Mehlich, 1953; Mylavarapu and Kennelley, 2002). The Mehlich-1 soil test extractant is currently used in several southeastern U.S. states for predicting fertilizer needs on sandy soils. Lime requirement (2 tons/acre) was determined with the Adams-Evans test (Adams and Evans, 1962; Hanlon et al., 1990). The soil averaged (six samples) medium ( $38 \mathrm{ppm}$ Mehlich-1 K) and the recommended rate of $\mathrm{K}$ was $84 \mathrm{lb} /$ acre (Hochmuth et al., 2004b). The Mehlich-1 soil test $\mathrm{K}$ ranged from 30 to $48 \mathrm{ppm}$ (average $=38 \mathrm{ppm}$ ) across the six soil samples tested in the research field area.

Soil was lifted into raised prebeds on 4 - $\mathrm{ft}$ centers with single-disc hillers preceded by a subsoiler shank (20 inches deep). Plots (experimental units) were $20 \mathrm{ft}$ in length with a 5 $\mathrm{ft}$ nonplanted and nonfertilized area between the end of one plot and the beginning of the next. Preplant fertilizer mixtures were sprinkled on the surface of the beds. Fertilizer materials and application rates were triple superphosphate $(70 \mathrm{lb} /$ acre $\mathrm{P})$, manganese sulfate $(1 \mathrm{lb} /$ acre $M n)$, and zinc sulfate $(\mathrm{llb} / \mathrm{acre} \mathrm{Zn})$. Ammonium nitrate and potassium nitrate were used to supply a uniform amount of $\mathrm{N}$ to the soil in each plot. Ammonium nitrate alone was applied to the soil in plots for the zero-K treatment. Totals of $\mathrm{N}$ and $\mathrm{K}$ applied preplant were $17 \mathrm{lb} /$ acre each (Table 1). Following preplant fertilizer application, the soil in the prebeds was rototilled and pressed into firm beds 6 inches in height with 24 inches across the top surface.

Carrot cultivar Scarlet Nantes (a Nantes-type) or Choctaw (an Imperator-type), from Sunseeds (Nunhems USA Inc., Parma, Idaho) and planting date (23 Nov. 1994, 14 Dec. 1994, or 17 Jan. 1995) were factorially arranged with $\mathrm{K}$ rate. Both cultivars are used for fresh-market sales. The experiment was a randomized complete-block design with five replicates.

Carrot seeds were mechanically seeded in two rows on the bed with 12 inches between rows, and plants were thinned at the first true-leaf stage to a final spacing of 1 inch for a final plant population target of 261,400 seedlings/acre. This plant population target is typical of commercial carrot production in the southeastern U.S. Carrots were irrigated with a solid-set sprinkler irrigation system to supplement rainfall and maintain soil moisture tension at $-10 \mathrm{kPa}$ measured by a tensiometer with the ceramic tip positioned 6 inches deep in the bed. Weeds were controlled by periodic hoeing.

The remaining $\mathrm{K}$ amounts, comprising each K treatment, were applied in three applications through the season (Tablel). The applications were made at first true-leaf, when plants were 4 inches tall, and when plants were 6 inches tall. Additional $\mathrm{N}$ also was applied through the season, with the K, in three sidedressings of 30,50 , and $50 \mathrm{lb} /$ acre, targeting a total-season amount of $150 \mathrm{lb} /$ acre. Nitrogen and K fertilizers (Table 1 ) were supplied from mixtures of ammonium nitrate and potassium nitrate (ammonium nitrate only for the carrots receiving zero-K). Fertilizer mixtures were applied by hand to the surface of the bed between the two rows of plants and lightly incorporated with a four-

Table 1. Potassium (K) applications and rates for fertilization of carrot at Gainesville, Fla., in Winter 1994-95.

\begin{tabular}{|c|c|c|c|c|c|}
\hline \multirow[b]{3}{*}{ Treatment } & \multicolumn{5}{|c|}{$\mathrm{K}$ fertilizer $(\mathrm{lb} / \mathrm{acre})^{\mathrm{z}}$} \\
\hline & \multirow[b]{2}{*}{ At planting } & \multicolumn{3}{|c|}{ Sidedressing $^{\mathrm{y}}$} & \multirow[b]{2}{*}{ Total } \\
\hline & & First & Second & Third & \\
\hline 1 & 0 & 0 & 0 & 0 & 0 \\
\hline 2 & 17 & 0 & 17 & 8 & 42 \\
\hline 3 & 17 & 17 & 25 & 25 & 84 \\
\hline 4 & 17 & 25 & 50 & 33 & 126 \\
\hline 5 & 17 & 46 & 60 & 45 & 168 \\
\hline
\end{tabular}


tined potato rake. Soil used for this study tested medium in $\mathrm{Mg}$; therefore, magnesium sulfate was applied at 20 $\mathrm{lb} / \mathrm{acre} \mathrm{Mg}$ in each of the first two sidedressings.

Weather conditions during Nov. 1994 through May 1995 were conducive for carrot growth at this site in northern Florida. The lowest temperature recorded during the season was $16{ }^{\circ} \mathrm{F}$ on $9 \mathrm{Feb}$. 1995; however, carrots were not damaged by the freezing temperature. Rainfall was sporadic during the winter of 1994-95 with total rainfall as follows (inches): November (0.04), December (0.91), January (4.41), February (1.06), March (4.29), April (5.91), and May (3.19). There were only four moderate rainfall events during the season: 3.19 inches on 15 Jan. (just before preplant fertilization and seeding of the second carrot planting), 2.72 inches on 19 Mar., 2.80 inches on 6 Apr., and 2.24 inches on 11 May. None of the rainfall events were considered to have resulted in significant leaching of $\mathrm{K}$ from the root zone (Hochmuth and Hanlon, 2000). The root zone was considered to be 12 inches deep.

Most recently matured whole leaves (blade plus petiole) were collected for determination of $\mathrm{K}$ concentration when the plants were 6 inches tall for the first two carrot plantings. Plants were 6 inches tall at $80 \mathrm{~d}$ in the November and December plantings. Plant materials were dried in a forced-air oven at $150{ }^{\circ} \mathrm{F}$, ground to pass a $0.6-\mathrm{mm}$ screen, digested in sulfuric/perchloric acids, and analyzed for K by plasma emission spectroscopy (Jones et al., 1991; Mylavarapu and Kennelley, 2002).

Carrots in all plots for each planting date were harvested when most roots had attained a length of 6 inches in treatment number $4(126 \mathrm{lb} /$ acre $\mathrm{K})$ treatment. The specific growing period, therefore, varied with planting date and cultivar (Table 2). Use of this approach to determine harvesting date was a compromise of the potentially best harvest dates for carrots within each respective Kfertilization program. Waiting for carrots with very low rates of $\mathrm{K}$ fertilization to gain market size might have taken too long to be practical commercially and would risk excessive sizing of carrots with greater $\mathrm{K}$ rates.

All carrots in both rows in a plot were loosened from the soil by undercutting below the root tip with a lifting blade. The roots with tops still attached were washed under a garden hose and graded according to U.S. Department of Agriculture grade standards (USDA, 1965). The yield grades were large (1.5- to 2.5 -inch diameter) and U.S. No. 1 (0.75 to 1.5 inches). The minimum marketable root length was 5 inches. Roots failing to meet minimum size standards or those misshapen or cracked were classified as cull.

Five carrots from the U.S. No. 1 grade were randomly selected for each experimental unit and the shoots were removed. The roots and shoots were placed in separate paper bags and fresh weights were determined. The selected five roots and shoots were dried in a forced-air oven until constant weight. Dry weights were used to calculate dry matter content of the roots and root: shoot ratios, based on dry matter. The roots and shoots were analyzed for K content.

Shoots were removed (and discarded) from the remaining carrots in the U.S. No. 1 grade category and from roots in other grade categories for each plot. The roots in each grade for each experimental unit were counted and fresh weights were determined. The fresh weight of the five selected roots (from above) was added to the fresh weight of the remaining roots for each plot to comprise the total-plot U.S. No. 1 root yield. Total marketable root yield was the sum of large plus U.S. No. 1 roots.

After plot yields were recorded as above, an additional 15 roots in each experimental unit were randomly selected from the U.S. No. I class for laboratory determination of total alcohol soluble sugars (Dubois et al., 1956) and total carotene concentration from a hexane extract (Umiel and Gabelman, 1971). The roots were cut into pieces and frozen at $-15^{\circ} \mathrm{F}$ while awaiting laboratory preparation and analysis.

Data were analyzed by analysis of variance to determine significance of main effects and presence of two- and three-way interactions among planting date, cultivar, and $\mathrm{K}$ rate (SAS release 8.02 for Windows; SAS Institute, Cary, N.C.). Significant K rate main effects were investigated further with regression analysis, and means comparisons (least significant difference, $P=0.05$ ) were used for evaluating planting date by cultivar simple effects.

Table 2. Planting and harvesting dates and growing season length for three carrot plantings at Gainesville, Fla., in 1994-95.

\begin{tabular}{lllcc}
\hline \multirow{2}{*}{$\begin{array}{l}\text { Planting } \\
\text { no. }\end{array}$} & Cultivar & \multicolumn{2}{c}{ Dates } & \multirow{2}{*}{$\begin{array}{c}\text { Growing } \\
\text { season }(\mathbf{d})\end{array}$} \\
\cline { 3 - 4 } 1 & Scarlet Nantes & 23 Nov. & 4 Apr. & 132 \\
& Choctaw & 23 Nov. & 10 Apr. & 138 \\
2 & Scarlet Nantes & 14 Dec. & 17 Apr. & 124 \\
& Choctaw & 14 Dec. & 20 Apr. & 127 \\
3 & Scarlet Nantes & 17 Jan. & 15 May & 118 \\
& Choctaw & 17 Jan. & 20 May & 123 \\
\hline
\end{tabular}

Table 3. Main effects (averaged across two cultivars, three planting dates, and five replicates) of potassium (K) fertilization on several carrot yield parameters at Gainesville, Fla., in 1994-95.

\begin{tabular}{|c|c|c|c|c|c|c|}
\hline \multirow{3}{*}{$\begin{array}{l}\text { K } \\
\text { fertilization } \\
(\text { lb } / \text { acre })^{x}\end{array}$} & \multicolumn{4}{|c|}{ Carrot root yield (tons /acre) $)^{\mathrm{z}}$} & \multirow{2}{*}{\multicolumn{2}{|c|}{$\begin{array}{c}\text { Carrots } \\
(\text { no. } / \text { acre } \times 1000)^{\mathrm{y}}\end{array}$}} \\
\hline & \multirow{2}{*}{$\begin{array}{l}\text { U.S. } \\
\text { No. } 1\end{array}$} & \multirow{2}{*}{\multicolumn{2}{|c|}{$\begin{array}{cc} & \text { Total } \\
\text { Large } & \text { marketable }\end{array}$}} & \multirow[b]{2}{*}{ Cull } & & \\
\hline & & & & & Marketable & Cull \\
\hline 0 & 7.98 & 0.10 & 8.08 & 2.41 & 122.8 & 81.2 \\
\hline 42 & 8.91 & 0.14 & 9.05 & 2.10 & 124.1 & 66.4 \\
\hline 84 & 9.15 & 0.17 & 9.32 & 2.23 & 132.5 & 70.0 \\
\hline 126 & 8.98 & 0.30 & 9.28 & 2.10 & 133.9 & 65.5 \\
\hline 168 & 8.49 & 0.32 & 8.81 & 2.39 & 126.3 & 75.3 \\
\hline $\begin{array}{l}\text { Response } \\
(P)\end{array}$ & $\begin{array}{c}\text { NS } \\
(0.074)\end{array}$ & $\begin{array}{c}\mathrm{L}^{*} \\
(0.028)\end{array}$ & $\begin{array}{c}\text { NS } \\
(0.055)\end{array}$ & $\begin{array}{c}\text { NS } \\
(0.220)\end{array}$ & $\begin{array}{c}\text { NS } \\
(0.273)\end{array}$ & $\begin{array}{c}\text { NS } \\
(0.120)\end{array}$ \\
\hline
\end{tabular}

${ }^{\mathrm{z}} 1$ ton $/$ acre $=2.2417 \mathrm{Mg} \cdot \mathrm{ha}^{-1}$.

y 1000 carrots $/$ acre $=2471$ carrots $/$ ha

${ }^{x} \mathrm{l} \mathrm{lb} /$ acre $=1.1209 \mathrm{~kg} \cdot \mathrm{ha}^{-1}$

Ns, ${ }^{*}$ Nonsignificant or significant at $P \leq 0.05$, respectively; $\mathrm{L}=$ linear. 


\section{Results and discussion}

There were no two- or three-way interactions involving $\mathrm{K}$ rate affecting any of the yield variables. Yield of U.S. No. 1 carrots was not affected by $\mathrm{K}$ fertilization (Table 3 ). The contrast of zero $\mathrm{K}$ fertilizer vs. fertilizer was nonsignificant $(P=0.161)$ and the contrast of zero K fertilizer vs. $84 \mathrm{lb} /$ acre K was nonsignificant $(P=0.153)$. Potassium fertilization increased the yield of large carrots slightly from 0.1 to 0.32 ton/acre. The model was:

$$
\begin{aligned}
& \text { Yield (tons } / \text { acre) } \\
& \quad=0.0827+0.001199 \mathrm{~K}
\end{aligned}
$$

where $\mathrm{K}$ is rate of $\mathrm{K}$ in pounds per acre. Large-size carrots made up, at most, less than $4 \%$ of the total marketable carrot yield. Amount and number of cull carrots were not influenced by $\mathrm{K}$ fertilization. Most cull carrots were undersized, less than 5 inches in length. Total marketable carrot yield (U.S. No. 1 plus large) was not affected by Kfertilization on this soil. The contrast of zero Kfertilizer vs. fertilizer was nonsignificant $(P=0.118)$ and the contrast of zero K fertilizer vs. $84 \mathrm{lb} /$ acre Kwas nonsignificant $(P=0.141)$. Number of marketable carrots was not affected by $\mathrm{K}$ fertilization. Marketable yield, averaged over cultivar, planting date, and replicate in this study was slightly less than yield reported by Phatak et al. (1998) for a December planting in Georgia. Numbers of harvested carrots in this study were similar to those reported by Phatak et al. (1998).

The soil used for this study tested medium (average $=38 \mathrm{ppm}$ ) in $\mathrm{Me}$ hlich-1 extractable K. Under medium soil test conditions, $70 \%$ to $100 \%$ typical yield is expected (Maynard and Hochmuth, 1997). The range (University of Florida Cooperative Extension Service) for the Mehlich-1 test medium category is 36 to $60 \mathrm{ppm} \mathrm{K}$ (Hochmuth and Hanlon, 1995). Any soil sample in this range would receive a recommendation of $84 \mathrm{lb} /$ acre $\mathrm{K}$ (Hochmuth et al., 2004b). The lack of response to $\mathrm{K}$ in this study indicates that the fertilizer recommendations are conservative and would err on the side of making a small K fertilizer recommendation when no fertilizer is required. There have been studies with other vegetables measuring responses to $\mathrm{K}$ fertilization. No response was observed for strawberry (Fragaria $\times$ ananassa) in two seasons on sandy soils testing 27 (low) and 46 (medium) Mehlich-1 K (Albregts et al., 1996). Slight responses to K fertilization were observed on similar sandy soils with snap bean (Phaseolus vulgaris)(Rhoads etal., 1990), tomato (Lycopersiconesculentum) (Hochmuth et al., 1991), and eggplant (Solanum melongena) (Hochmuth et al., 1992). There was no carrot response to $\mathrm{K}$ fertilization in an early 3 -year study in central Florida on a sandy soil (Forbes and Westgate, 1963). The field used for that study had been in continuous vegetable production for 50 years and had a high level of residual $\mathrm{K}$, reported to be $240 \mathrm{lb} /$ acre K (soil test extractant not reported). Carrot yield did not respond to $\mathrm{K}$ fertilization (no soil test results presented) of a loamy fine sandy soil in California (Tyler, 1986).

Root length and root diameter were not affected by $\mathrm{K}$ fertilization (Table 4). We used root: shoot ratio as an indicator of efficiency of root production in relation to shoot growth.
Growers sometimes associate greater shoot growth with greater root yields. Greater root: shoot ratios would indicate more efficient root production, which is desirable for carrots. The root: shoot ratio was not affected by $\mathrm{K}$ fertilization (Table 4).

Accumulation of K by U.S. No. 1 carrot roots increased quadratically with $\mathrm{K}$ rate, but shoot $\mathrm{K}$ uptake was not affected by $\mathrm{K}$ rate (Table 4 ). The model for root accumulation was:

$$
\begin{aligned}
\text { Root K } & (\mathrm{lb} / \text { root }) \\
& =4.14 \times 10^{-4}+1.83 \\
& \times 10^{-6} \mathrm{~K}-7.68 \times 10^{-9} \mathrm{~K}^{2}
\end{aligned}
$$

where $\mathrm{K}$ is $\mathrm{K}$ rate in pounds per acre. Root (U.S. No. 1 roots) K accumulation was maximized at $68 \mathrm{lb} /$ acre with $120 \mathrm{lb} /$ acre Kfertilizer, using the average value of 127,920 roots per acre for the plant population (calculated from Table 3). The average shoot $\mathrm{K}$ accumulation was $28 \mathrm{lb} /$ acre. Maximum calculated total plant $\mathrm{K}$ accumulation was $96 \mathrm{lb} /$ acre (summing $68 \mathrm{lb} /$ acre U.S. No. 1 root uptake with $28 \mathrm{lb} /$ acre shoot uptake). With no K fertilization, carrot plants accumulated an average total of $78 \mathrm{lb} /$ acre K $($ root $=53 \mathrm{lb} /$ acre and shoots $=25 \mathrm{lb} /$ acre $)$. The $\mathrm{K}$ in the plants with the control treatment came from the native $K$ in this soil that tested medium in soil test Kconcentration. The lack of carrot yield response, coupled with the plant Kaccumulation results, indicate this soil would more appropriately be referred to as "high" in Mehlich-1 K. Soils with this Mehlich-1 $\mathrm{K}$ soil test result should receive a lower $\mathrm{K}$ recommendation than is currently made, perhaps even zero $\mathrm{K}$.

Potassium concentration in leaves of 6-inch tall plants increased quadrati-

Table 4. Main effects (averages across two cultivars, three planting dates, and five replicates) of potassium (K) fertilization for several carrot root and shoot parameters at Gainesville, Fla., in 1994-95.

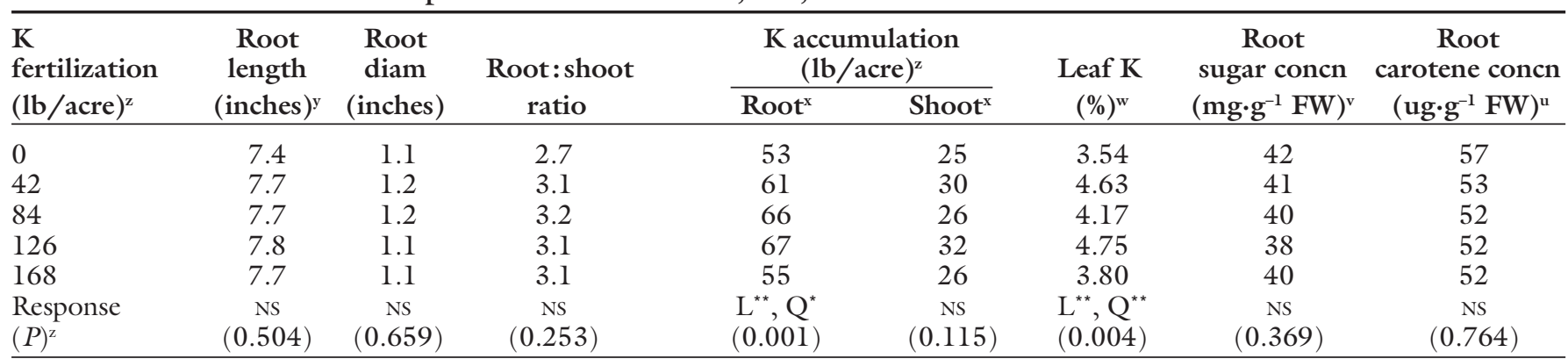

\footnotetext{
${ }^{\mathrm{z}} 1 \mathrm{lb} / \mathrm{acre}=1.1209 \mathrm{~kg} \cdot \mathrm{ha}^{-1}$.

y 1 inch $=2.54 \mathrm{~cm}$.

${ }^{x}$ Using the average plant population of 127,920 roots/acre $(316,086$ roots $/$ ha $)$.

wLeaf-K concentration measured at 6 -inch height growth stage for only the first two plantings.

${ }^{\mathrm{V}} \mathrm{l} \mathrm{mg} \cdot \mathrm{g}^{-1}=1000 \mathrm{ppm}$.

"l $\mathrm{ug} \cdot \mathrm{g}^{-1}=1 \mathrm{ppm}$.

Ns, ${ }^{*},{ }^{* *}$ Nonsignificant or significant at $P \leq 0.05$ or 0.01 , respectively; $\mathrm{L}=$ linear; $\mathrm{Q}=$ quadratic.
} 
cally with K fertilization (Table 4). Leaf Kconcentration was maximized at $4.6 \%$ with $105 \mathrm{lb} /$ acre $\mathrm{K}$. The model was:

$$
\begin{aligned}
\text { Leaf } \mathrm{K}(\%) & =3.625+0.0166 \mathrm{~K} \\
& -0.0000789 \mathrm{~K}^{2}
\end{aligned}
$$

where $\mathrm{K}$ is $\mathrm{K}$ rate in pounds per acre. This maximum leaf-K concentration was slightly greater than the upper limit of the recommended ranges of $2.0 \%$ to $4.0 \%$ of Hochmuth et al. (2004a) and Jones et al. (1991), and 2.8\% to $4.5 \%$ of Weir and Cresswell (1993). The leaf- $K$ results showed that carrot plants had adequate $\mathrm{K}$. It is not possible to determine a critical leaf- $K$ concentration when there was no yield response to $\mathrm{K}$ fertilization. Most of the increase in leaf- $\mathrm{K}$ concentration occurred between the first two treatments. Even though K concentration in leaves increased with K fertilization, an increase in total shoot accumulation was not detected.

Potassium fertilization had no influence on carrot root quality. Total sugar concentration [average $=40$ $\mathrm{mg} \cdot \mathrm{g}^{-1}$ fresh weight $\left.(\mathrm{FW})\right]$ was not affected by $\mathrm{K}$ fertilization (Table 4 ). In another study, $\mathrm{K}$ fertilization led to lower concentrations of reducing sugars in carrot (Ali et al., 2003). Greater taste preference for carrot was related to reduced volatile-chemical and increased sugar concentrations in a study of carrots from three states (Simon and Peterson, 1979). Total sugar concentrations were slightly greater for carrots from California and Wisconsin than Florida. These researchers reported similar total sugar concentrations for Florida carrots as reported in the present study.
Carotenoid concentrations were not influenced by Kfertilization (Table $4)$. These results are in contrast to those of Ali et al. (2003), where K fertilization led to increases in carotene content from $9.5 \mathrm{ug} \cdot \mathrm{g}^{-1}$ with $0 \mathrm{~K}$ to 21.9 ug. ${ }^{-1}$ with $220 \mathrm{lb} /$ acre K. Carotene concentrations of carrots reported in the study of Ali et al. (2003) were lower than carotene concentrations in the present study (average of 54 ug. $\mathrm{g}^{-1} \mathrm{FW}$ ). Carotene concentration was enhanced by banding of $\mathrm{P}$ and $\mathrm{K}$ together in a study in Finland (Evers, 1989a). The carotene concentrations $\left(25\right.$ to $\left.65 \mathrm{ug} \cdot \mathrm{g}^{-1}\right)$ in the Finland study were similar to carotene concentrations in the present study. $\mathrm{K}$ fertilization in the present study led to no increases in yield and likewise Kfertilization had no effects on the compositional quality of roots. Native soil K was sufficient to produce optimal yields and highest root quality.

Carrot root yield variables were influenced by the interaction of planting date and cultivar (Table 5). With the first planting date, U.S. No. 1 yield of 'Choctaw' was greater than for 'Scarlet Nantes'. Yields from the second and third plantings of the two cultivars were similar. Large-root yield of 'Scarlet Nantes' was greater than 'Choctaw' for the first planting, but large-root yields for the two cultivars were similar for the December and January plantings. Total marketable root yield of 'Choctaw' was greater than 'Scarlet Nantes' for the first planting date. Yields were similar between the two cultivars for the second and third planting dates. Numbers of marketable carrots were greater for 'Choctaw' than 'Scarlet
Nantes' for the first and second planting dates (Table 5). Numbers were similar for the third planting date. 'Choctaw', a newer cultivar, could be more vigorous in the seedling stage than 'Scarlet Nantes', resulting in greater crop plant populations. Seedling mortality was high for 'Scarlet Nantes', especially in the first and third plantings, but the specific reasons for the loss in plant stand are not known.

Yields of most cultivars were greater for fall plantings than winter in an early study in Florida (Forbes and Scudder, 1963). Those authors concluded that warm fall growing conditions in central Florida were important for early plant growth and cooler winter weather was important for root development. Yields of cull roots were similar for the two cultivars for the first two plantings. 'Choctaw' produced more cull roots than 'Scarlet Nantes' in the third planting. The marketable yield for 'Choctaw' from the 23 Nov. planting averaged 13.9 tons/acre (Table 5), which is similar to 'Choctaw' yield from a December planting in Georgia (Phatak et al., 1998). Fresh market carrots often are packaged in $50-1 b$ units, and 13.9 tons/acre equals 550 units per acre. Production costs were estimated to be $\$ 2077$ /acre in a study in Georgia (Westberry, 1998). In that study, carrot returns were $\$ 6.00$ per unit, which would result in a net return of $\$ 1220 /$ acre for carrots in the current Florida study.

Root growth, $\mathrm{K}$ accumulation, and root quality parameters were also influenced by the interaction of planting date and cultivar (Table 6). Root diameter was greater for 'Scarlet

Table 5. Interaction effects of planting date and carrot cultivar [averaged across five potassium (K) rates

\begin{tabular}{|c|c|c|c|c|c|c|c|}
\hline \multirow{3}{*}{$\begin{array}{l}\text { Planting } \\
\text { date }\end{array}$} & \multirow{3}{*}{$\begin{array}{l}\text { Carrot } \\
\text { cultivar }\end{array}$} & \multicolumn{4}{|c|}{ Carrot root yield (tons /acre) ${ }^{\mathrm{z}}$} & \multirow{2}{*}{\multicolumn{2}{|c|}{$\begin{array}{c}\text { Carrots } \\
(\text { no. } / \text { acre } \times 1000)^{y}\end{array}$}} \\
\hline & & \multirow{2}{*}{$\begin{array}{l}\text { U.S. } \\
\text { No. } 1\end{array}$} & \multicolumn{3}{|c|}{$\begin{array}{l}\text { Total } \\
\end{array}$} & & \\
\hline & & & Large & marketable & Cull & Marketable & Cull \\
\hline \multirow[t]{2}{*}{23 Nov. } & Scarlet Nantes & 9.87 & 0.98 & 10.85 & 1.37 & 128.1 & 29.4 \\
\hline & Choctaw & 13.84 & 0.06 & 13.90 & 1.31 & 190.8 & 39.6 \\
\hline \multirow[t]{2}{*}{14 Dec. } & Scarlet Nantes & 7.73 & 0.01 & 7.74 & 2.72 & 118.7 & 90.7 \\
\hline & Choctaw & 8.13 & 0.0 & 8.13 & 3.46 & 138.3 & 122.2 \\
\hline \multirow[t]{2}{*}{17 Jan. } & Scarlet Nantes & 5.78 & 0.06 & 5.84 & 1.43 & 89.9 & 47.4 \\
\hline & Choctaw & 6.84 & 0.11 & 6.95 & 3.17 & 101.9 & 100.9 \\
\hline \multirow{2}{*}{\multicolumn{2}{|c|}{$\begin{array}{l}\text { Planting date } \\
\times \text { cultivar }\end{array}$}} & & & & & & \\
\hline & & 0.0001 & 0.0001 & 0.001 & 0.0001 & 0.001 & 0.004 \\
\hline \multicolumn{8}{|l|}{ Interaction } \\
\hline$\left(\mathrm{LSD}^{\mathrm{x}}, P=0.05\right.$ & & 1.70 & 0.30 & 1.20 & 0.70 & 15.7 & 33.1 \\
\hline
\end{tabular}
and five replicates] on carrot root yield parameters at Gainesville, Fla., in 1994-95. 
Table 6. Interaction effects [averaged across five potassium (K) rates and five replicates] of planting date and carrot cultivar on several carrot root and shoot parameters at Gainesville, Fla., in 1994-95.

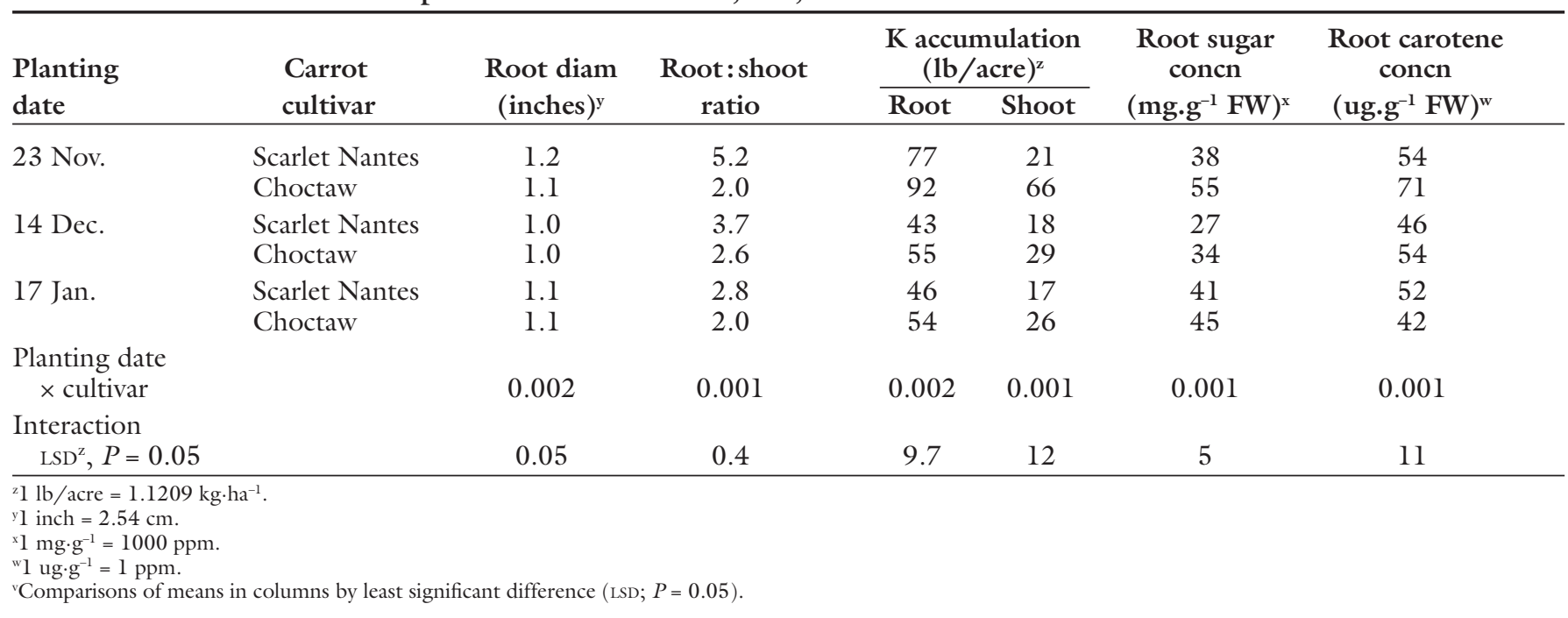

Nantes' for the first planting date but the diameters of the two cultivars were similar for the second and third planting dates. The root: shoot ratio was greater for 'Scarlet Nantes' than 'Choctaw' for all three planting dates, but the difference was less pronounced for the second and third dates compared with the first date.

'Choctaw' accumulated more $\mathrm{K}$ in the root and shoot, compared with 'Scarlet Nantes', for all planting dates (Table 6), but the degree of difference varied with the dates. The difference in $\mathrm{K}$ accumulation was greater with the first planting date. 'Choctaw' was generally observed to be a more vigorous plant than 'Scarlet Nantes'. Root uptake of $\mathrm{K}$ ranged from 43 to $92 \mathrm{lb} /$ acre and shoot uptake ranged from 17 to $66 \mathrm{lb} /$ acre. Total plant K uptake was greatest ( $158 \mathrm{lb} /$ acre $\mathrm{K}$ ) with 'Choctaw' in the first planting date.

'Choctaw' roots had greater sugar concentrations than 'Scarlet Nantes' for the first and second planting dates, but sugar concentration was similar for the two cultivars in the third planting date. Carotenoid concentration was greater for 'Choctaw' than 'Scarlet Nantes' for the first planting date, but the concentrations of carotenoid compounds were similar for the two cultivars for the second and third planting dates. Sugar and carotenoid concentrations did not appear to be related to either root size or root: shoot ratio. Carrot cultivars are well-known for differences in carotenoid contents. Large differences were noted among carrot cultivars for carotenoid concentrations (range was
55 to $274 \mathrm{ug} \cdot \mathrm{g}^{-1} \mathrm{FW}$ ) in Wisconsin (Umiel and Gabelman, 1971). There were genetic and environmental variations for carotenoid compounds and sugars measured among carrot cultivars grown in Wisconsin, California, and Florida (Simon and Peterson, 1979; Simon et al., 1982).

\section{Conclusion}

Total marketable carrot yield did not respond to K fertilization on sandy soils in Florida testing $38 \mathrm{ppm}$ (medium) in Mehlich-1 K. The current K recommendation of $84 \mathrm{lb} /$ acre $\mathrm{K}$ on these soils could be reduced without sacrificing yield. These results may also apply elsewhere in the southeastern U.S. with sandy soils similar to the soil used in this study. Whole-leaf tissue $\mathrm{K}$ concentration of $4.0 \%$ to $4.6 \%$ at the 6-inch plant height stage of growth was indicative of sufficient $\mathrm{K}$ fertilization. Carrot root compositional quality factors (sugar and carotenoid concentrations) were not affected by K fertilization. 'Choctaw' yield and carotene and sugar concentrations were greater than those for 'Scarlet Nantes' for the early planting, but these variables were similar for the cultivars for the later two plantings. High carrot yields and high-quality carrots were grown on this medium- $\mathrm{K}$ sandy soil without $\mathrm{K}$ fertilization.

\section{Literature cited}

Adams, F. and C.E. Evans. 1962. A rapid method for measuring lime requirement of red-yellow podzolic soils. Soil Sci. Soc. Amer. Proc. 26:355-357.
Albregts, E.E., G.J. Hochmuth, C.K. Chandler, J. Cornell, and J. Harrison. 1996. Potassium fertigation requirements of drip-irrigated strawberry. J. Amer. Soc. Hort. Sci. 121:164-168.

Ali, A., M.A. Hossain, F. Mondal, and A.M. Farooque. 2003. Effect of nitrogen and potassium on yield and quality of carrot. Pakistan J. Biol. Sci. 6:1574-1577.

Boswell, V.R. 1963. Commercial growing of carrots. U.S. Dept. Agr. Lflt. No. 353.

Conrow, R.C. 1989. Draft SWIM plan for Lake Apopka. St. Johns River Water Mgt. Dist. Misc. Publ. St. Johns River Water Management District, Palatka, Fla.

Crnko, G.S., A. Ferrer, E.A. Hanlon, C.A. Neal, and J.M. White. 1993. Carrot and sweet corn yields when fertilized according to soil test results. Proc. Fla. State Hort. Soc. 106:199-201.

Dubois, M., K.A. Gilles, J.K. Hamilton, P.A. Rebers, and F. Smith. 1956. Colorimetric method for determination of sugars and related substances. Anal. Chem. 28:350-356.

Evers, A.-M. 1988. Effects of different fertilization practices on the growth, yield, and dry matter content of carrot. J. Agr. Sci. Finland 60:135-152.

Evers, A.-M. 1989a. Effects of different fertilization practices on the carotene content of carrot. J. Agr. Sci. Finland 61:7-14.

Evers, A.-M. 1989b. The role of fertilization practices in the yield and quality of carrot (Daucus carota L.). J. Agr. Sci. Finland 61:329-360.

Florida Agr. Stat. Serv. 1997. Florida agricultural statistics. Vegetable summary. Florida Agr. Stat. Serv., Orlando. 
Follett, R.F. 1991. Seasonal sucrose, dry matter, and cation concentrations of sugarbeet as influenced by variety and $\mathrm{N}$ fertilization. Commun. Soil Sci. Plant Anal. 22:893-906.

Forbes, R.B. and W.T. Scudder. 1963. Carrot planting date trials in central Florida. Proc. Fla. State Hort. Soc. 76:194-195.

Forbes, R.B. and P.J. Westgate. 1963. Carrot fertilization experiments in central Florida. Soil Crop Sci. Soc. Fla. Proc. 23:99-104.

Freeman, J.A. and G.H. Harris. 1951. The effect of nitrogen, phosphorus, potassium, and chlorine on the carotene content of the carrot. Sci. Agr. 31:207-211.

Hanlon, E.A., G. Kidder and B.L. McNeal. 1990. Soil, container media, and water testing. Fla. Coop. Ext. Serv. Circ. 817. Univ. Fla., Gainesville.

Hartz, T.K., P.R. Johnstone, and J.J. Nunez. 2005. Production environment and nitrogen fertility affect carrot cracking. HortScience 40:611-615.

Hemphill, D.D., Jr. and T.L. Jackson. 1982. Effect of soil acidity and nitrogen on yield and elemental concentration of bush bean, carrot, and lettuce. J. Amer. Soc. Hort. Sci. 107:740-744.

Hipp, B.W. 1978. Response by carrots to nitrogen and assessment of nitrogen status by plant analysis. HortScience 13:43-44.

Hochmuth, G.J., J.K. Brecht, and M.J. Bassett. 1999. Nitrogen fertilization to maximize carrot yield and quality on a sandy soil. HortScience 34:641-645.

Hochmuth, G. and E. Hanlon. 1995. IFAS Standardized fertilization recommendations for vegetable crops. Fla. Coop. Ext. Serv. Circ. 1152

Hochmuth, G.J. and E.A. Hanlon. 2000. Commercial vegetable fertilization principles. Fla. Coop. Ext. Serv. Circ. 225E. 3 Jan. 2006. <http://edis.ifas.ufl.edu/ CV009>.

Hochmuth, G.J., E.A. Hanlon, P.R. Gilreath, and K.D. Shuler. 1991. Effects of K rates on yield of tomato at three commercial production sites. Soil Crop Sci. Soc. Fla. Proc. 50:169-172.

Hochmuth, G.J., R.C. Hochmuth, E.A. Hanlon, and M.E. Donley. 1992. Effect of potassium on yield and leaf- $\mathrm{N}$ and $\mathrm{K}$ concentrations of eggplant. Fla. Agr. Expt. Sta. Rpt., Suwannee Valley Agr. Res. and Edu. Ctr. 92-2.
Hochmuth, G., D. Maynard, C. Vavrina, E. Hanlon, and E. Simonne. 2004a. Plant tissue analysis and interpretation for vegetable crops in Florida. Fla. Coop. Ext. Serv. Univ. Fla., Gainesville. 3 Jan. 2006. <http://edis.ifas.ufl.edu/EP08l>.

Hochmuth, G.J., D.N. Maynard, C.S. Vavrina, W.M. Stall, T.A. Kucharek, and S.E. Webb. 2004b. Carrot production in Florida. p. 117-122. In: S.M. Olson and E. Simonne (eds.). Vegetable production handbook for Florida. Fla. Coop. Ext. Serv., Univ. Fla., Gainesville.

Jones, J.B., B. Wolf, and H.A. Mills. 1991. Plant analysis handbook. Micro-Macro Publ., Athens, Ga.

Locascio, S.J., W.J. Wiltbank, D.D. Gull, and D.N. Maynard. 1984. Fruit and vegetable quality as affected by nitrogen nutrition, p. 617-626. In: R.D. Hauck (ed.). Nitrogen in crop production. Amer. Soc. Agron., Madison, Wis.

Maynard, D.N. and G.J. Hochmuth. 1997. Knott's handbook for vegetable growers, 4th ed. Wiley, New York.

Mehlich, A. 1953. Determination of $\mathrm{P}, \mathrm{Ca}$, $\mathrm{Mg}, \mathrm{K}, \mathrm{Na}$, and $\mathrm{NH}_{4}$. North Carolina Soil Testing Div. Mimeo, Raleigh.

Mengel, K. 1979. Influence of exogenous factors on the quality and chemical composition of vegetables. Acta Hort. 93:133-150.

Moore, W.D. 1949. Flooding as a means of destroying the sclerotia of Sclerotinia sclerotiorum. Phytopathology 39:920-927.

Mozafar, A. 1993. Nitrogen fertilizers and the amount of vitamins in plants: A review. J. Plant Nutr. 16:2479-2506.

Mylavarapu, R.S. and E.D. Kennelley. 2002. UF/IFAS Extension Soil Testing Laboratory (ESTL) analytical procedures and training manual. Univ. Fla. Coop. Ext. Serv. Circ. 1248. Univ. Fla., Gainesville. 3 Jan. 2006. <http://edis.ifas.ufl. edu/SS312>.

Phatak, S.C., A.G. Bateman, and E. Cravey. 1998. Tift County carrot variety trials, p. 33-38. In: A.E. Reynolds (ed.). Carrot production and processing in Georgia. Univ. Georgia Agr. Expt. Sta. Res. Rpt. No. 653. Athens. 3 Jan. 2006. <http:// pubs.caes.uga.edu/caespubs/pubs/PDF/ RR653.pdf >.

Rhoads, F.M., E.A. Hanlon, S.M. Olson, and G.J. Hochmuth. 1990. Response of snap bean to $\mathrm{N}$ rates and soil-test $\mathrm{P}$ and $\mathrm{K}$. Soil Crop Sci. Soc. Fla. Proc. 49:10-13.
Rosenfeld, H.J., R.T. Samuelsen, and P.L. Matforsk. 1998. The effect of temperature on sensory quality, chemical composition, and growth of carrots (Daucus carota L.) I. Constant diurnal temperature. J. Hort. Sci. Biotechnol. 73:275-288.

Sanderson, K.R. and J.A. Ivany. 1997. Carrot yield response to nitrogen rate. J. Production Agr. 10:336-339.

Simon, P.W. and C.E. Peterson. 1979. Genetic and environmental components of carrot culinary and nutritive value. Acta Hort. 93:271-278.

Simon, P.W., C.E. Peterson, and R.C. Lindsay. 1980. Genetic and environmental influences on carrot flavor. J. Amer. Soc. Hort. Sci. 105:416-420.

Simon, P.W., C.E. Peterson, and R.C. Lindsay. 1982. Genotype, soil, and climate effects on sensory and objective components of carrot flavor. J. Amer. Soc. Hort. Sci. 107:644-648.

Southards, C.J. and C.H. Miller. 1962. A greenhouse study on the macroelement nutrition of the carrot. Proc. Amer. Soc. Hort. Sci. 81:335-340.

Strandberg, J.O. 1984. Flooding organic soils to control species of Pythium which attack carrots and other vegetables. Proc. Fla. State Hort. Soc. 97:164-168.

Tyler, K. 1986. Hybrid carrot mineral nutrition. California Coop. Ext. Serv. Veg. Briefs, Issue 256.

Umiel, N. and W.H. Gabelman. 1971. Analytical procedures for detecting carotenoids of carrot (Daucus carota L.) roots and tomato (Lycopersicon esculentum) fruits. J. Amer. Soc. Hort. Sci. 96:702-704.

U.S. Department of Agriculture. 1965. United States standards for grades of topped carrots. U.S. Dept. Agr., Washington, D.C.

Venter, F. 1979. Nitrate content in carrots (Daucus carota L.) as influenced by fertilization. Acta Hort. 93:163B172.

Weir, R.G. and G.C. Cresswell. 1993. Plant nutrient disorders. 3. Vegetable crops. Inkata Press, Melbourne, Australia.

Westberry, G. 1998. Costs and returns, p. 85-90. In: A.E. Reynolds (ed.). Carrot production and processing in Georgia. Univ. Georgia Agr. Expt. Sta. Res. Rpt. No. 653. Athens. 3 Jan. 2006. <http://pubs.caes. uga.edu/caespubs/pubs/PDF/RR653. $\mathrm{pdf}>>$.

Wong, A.D., J.M. Swaider, and J.A. Juvik. 1995. Nitrogen and sulfur fertilization influences aromatic flavor components in shrunken-2 sweet corn kernels. J. Amer. Soc. Hort. Sci. 120:771-777. 